\title{
BRAVE AND HARDWORKING: A FEMINIST ANALYSIS ON CHILDREN FAIRYTALE "THE LAZY GIRL"
}

\author{
Dewi Purnamasari ${ }^{1}$, Didin Nuruddin Hidayat ${ }^{2}$, Alek $^{3}$ \\ UIN Syarif Hidayatullah Jakarta \\ Ipurnamadewi814@gmail.com \\ 22didin.nuruddin@uinjkt.ac.id \\ 3 alek@uinjkt.ac.id
}

\begin{abstract}
This study analyzed the feminist analysis of children fairytale "The Lazy Girl". In this case, the researchers selected the children's fairytale from the perspective of modern feminism framework analysis and identified the moral values of this story. This study focused on the main character of the story drawn as a brave and hardworking character. The method used in this study is qualitative descriptive analysis with an ideational meta-function approach in analyzing the data. The data collected from the synopsis of the "The Lazy Girl" fairy tale. The researchers analyzed the text of the story from a YouTube channel based on the feminist approach. The finding showed that there were four main processes existed in fairytales' synopsis entitled these are material (44\%), mental (20\%), verbal (28\%), and relational process (18\%). While in feminism literal analysis, the researcher found that the second and the third wave of feminist characteristics were used in this story. The main character of this story showed the brave and hardworking of the young girl which related to the feminist framework. Besides, this story has good moral values for children and provides a positive impact on children.
\end{abstract}

Keywords: Feminist, Brave, Children Fairytale, Discourse Analysis

\begin{abstract}
ABSTRAK
Penelitian ini mengkaji analisa feminis dari dongeng anak-anak "The Lazy Girl (Si Gadis Pemalas)". Dalam kajian ini, peneliti meninjau sudut pandang dari kerangka analisis faminisme modern dalam dongeng anak-anak dan kemudian mengidentifikasi nilai-nilai moral dari cerita ini. Penelitian ini difokuskan pada karakter utama dari dongeng yang dikaji, yang digambarkan sebagai karakter yang berani dan pekerja keras. Metode yang digunakan dalam penelitian ini adalah analisis deskriptif kualitatif dengan pendekatan ideasional metafungsi dalam menganalisis data. Data diambil dari synopsis dongeng 'The Lazy Girl (Si Gadis Pemalas)'. Peneliti menganalisis teks cerita dari YouTube berdasarkan pendekatan feminis. Temuan ini menunjukkan bahwa ada empat tipe utama dalam sinopsi "the Lazy Girl" (sigadis pemalas) menurut analisis ideasional, yaitu proses material (44\%), proses mental (20\%), proses verbal (28\%), and prosess relasi (18\%).sedangkan dalam analisis teori feminis, peneliti menemukan gelombang kedua dan ketiga karakteristik feminis digunakan dalam cerita ini. Karakter utama dari cerita ini menunjukkan keberanian dan kerja keras gadis muda yang terkait dengan kerangka feminisme. Selain itu kisah ini memiliki nilai moral yang baik untuk anak-anak dan memberikan dampak positif bagi anak-anak.
\end{abstract}

Kata kunci: Feminis, Keberanian, Dongeng Anak, Analisis Wacana 


\section{INTRODUCTION}

A fairy tale is an old literary form that tells of an extraordinary event full of fantasy which is considered by society to be something that did not happen. Fairy tales are a form of traditional stories or stories that are passed down through ancestors. Furthermore, fairy tales serve to convey moral educational teachings and also entertain the children. Therefore, some children like to read or watch fairy tales from many sources, such as television, book, and YouTube. Many fairy tales have deep morals to learn and inculcate for the children and some of the fairy tale stories provide the children with an important message and moral. Although the themes in fairy tales are fiction, the effect in the fairytale is positive and offers good messages for children's development (Tatar, 2017). In some cases, fairy tales teach the children the basic human conflicts, the values, the good relationship, and their beliefs in the future.

The fairy tales are the story for a purpose, means that in fairy tales consist of the form of social education, the message of good moral and the important message of fairytales is to build the people to imagine the conflict in the story and how to solve these problems. On the other hand, fairy tales also provide the good and bad manners of the actors, labeling the socially acceptable and unacceptable behavior, find out the good and evil, exploring existential questions (Justice, 2014). This becomes important as parents to know and pay close attention to what our children do. Bettelheim states that "children need a moral education not through abstract ethical concepts but through that which seems tangibly right and therefore meaningful, the child finds this kind of meaning through fairy tales (Beynen, 1977)." Hence, it does not matter for the children to watch or read fairy tales

Many fairy tales have been published over the years, from the written fairytales up to digital fairytales. Traditionally, classic fairy tales are drawn from many sources, including ancient, mythology, pagan religion, morality plays, etc (Morrison, 2014). At the time the stories are simply original fantasies couched in the language and form of traditional fairytales. They are intended to be playful, sometimes funny, and sometimes thought-provoking. Although some of the readers ignored the fantasy element of a fairytale, they may still be fall prey to involve in the story through a paradigm by using the main character. Therefore, the subconsciously of a woman can transfer their existence from the fairytale into a real-life cultural norm which their independency, self-devotion as female virtues (Paxton, 2005). Some of the older classic fairytales which very hard to forget likes "Cinderella", "Beauty and The Beast" which drawn as young and beautiful princesses. In the story, Cinderella is described as a character who weak, passive, always on target, 
victimized, and needed the help of a prince who came to fetch her from the fight itself. These stories describe a woman as someone submissive, dependent, and detached, while the man as a person who strong, active, and dominant. It also looks good inside female compilation the story is understood as someone silent, without approval, beautiful, suburban, and happy to get married. The traditional feminism criticizes the classical fables because these stories reflected of patriarchal values that persist. Therefore, feminist writers rewrite a fairy tale so that it can include the discourse contradict or challenge patriarchal ideology which is increasingly seen as out of date in today's society (Kuykendal \& Sturm, 2007). In line with that, Margareth Fuller also had briefly drawn the feminist perspective at Cinderella story from the main character, she brings the women in the nineteenth century which in that era become the first move to introduce the fairytale into the public of women's right.

The Lazy Girl is one of the familiar digital fairytales that watch almost by the children this fairytale is used as material for children to teach a moral value. Furthermore, in this article, the researcher analyzed the modern feminist's framework throughout the digital fairytale "The Lazy Girl" and the study focused on a female character presented with brave and strong women that display a step-mother with daughter relationship. While, the majority of this fairytale follows a similar story, including a plot centered on finding an identity of the main character, a princess in need of saving from some physical or emotional. Besides, the researchers try to find out the moral message of this story.

\section{LITERATURE REVIEW}

A feminist message of some kind can be found embodied in each fairytale story (Loobeek, 2014). In this case, the role of fairytales in the cultural discourse on gender and many fairytale texts has been tacit awareness in discourse analysis. Demonstrating by Hendrick who describes "the continuity of feminist concerns in literacy history, these early commentaries in the forms of literary fairy tales not only prefigure the work in twentieth-century literature but also it comes to the film analysis Moreover, they also foreshadow the feminist critique articulated so vigorously in fairytale scholarship. Some feminist fairytale analyses and remain stuck in a mode of interpretation that can more than reconfirm stereotypical generalization about the sexist stereotype of fairy tales (Hendricks, 2013).”.

From the beginning, the feminist critique of fairytales has centered on depictions of the fairy tale heroine. It's depicted important to identify the main character of a fairytale to know the major shifts of the historical moment in the story and then by linking these shifts to known about the historical changes that affecting the women's ability to control their fertility (Al-Barazenji, 2015). One of the relevant 
studies in the feminist analysis was conducted by Look. In this cases she concern on a feminist analysis of the Film "THE HUNGER GAMES", This study began with a close examination of the cinematic version of The Hunger Games and feminism's history within the United States to date; it then delved into the inter-lapping sections of the two and analyzed the implications of said intersections. This study concluded that feminism is evident within The Hunger Games, with third-wave characteristics being most general in this film which rich in ideologies (Loobeek, 2014).

Feminism is a women's movement that focuses on the emancipation of women or the equality and the justice of rights with men. The term feminist began to be used in the 1890s, indicate to the theory of equality of men and women and the movement to get the women's rights. According to Beasley, the feminism theory is about advocating equality of women's rights in politics, in the economic matters, in the social equality of the sexes which includes organizing the women acting in their interest (Barbara, 1999). In this case, the new era of feminism began and brought up some views and characteristics of feminism. The First Wave came at the end of 1920 which focused on equal political rights for women, in this case, women demand their right to vote in political policy (Rudloff, 2016). While the Second Wave of feminism was centered on social issues. At this time, the women wanted an equal position in entering the workforce diversity and receive equal pay, and the reproductive issues about birth control (Lazar, 2005). Because in this era, many issues about abortion and birth control rights. The Third Wave of feminism began in the 1990s to respond to Second Wave feminism (Morrison, 2014). This wave focused on social issues for a woman's right but in this case, the stresses are to choose the traditional role for a woman as a housewife.

The story in fairytales rich in the moral message. In this case, the aim of the reader or the audience is to gain wisdom and for our learning to be better. Generally, moral is a behavior or character that is applied in each individual to be able to socialize properly and respect to other people. The moral word always refers to the good and bad of human actions. Dimerman argues that the top ten characters and morals are based on polling character matters Program participants. These are responsibility, respect, initiative, integrity, honesty, fairness, perseverance, empathy, and optimism (Dimerman, 2009). In time, feminism has grown into a critical theory. It focused essentially on the diversity of voices, points of view, and it is mainly about freedom from the patriarchal gender norms and also freedom from discrimination for all human beings. Feminist concentrates on the deconstruction of the binary woman/man, implicitly the binaries known and unknown, reason/feeling, and consciousness/unconsciousness.

Nowadays, the development of fairytale is very advanced. The people access 
fairytales not only through books or verbally. At this time one of the media accessible and easy to use by everyone is YouTube. YouTube as a type of mass media is becoming a channel for a variety of ideas, concepts, and can bring about plurality the effects of the views that ultimately lead to changes in a Public. In this case, it can be used to enter discourse feminists in the modern era. Additionally, the emergence of Fairytale on YouTube makes it easy for everyone to access it, one of the favorite fairytales of children is the lazy girl.

\section{RESEARCH METHOD}

The method used in this research was descriptive qualitative design. Descriptive qualitative analysis is a form of interpretive inquiry in which the researchers make interpretations of what they see, hear, and understand (Creswell, 2009). In this study, the researchers focused on the ideational meta-function analysis and modern feminist analysis framework. The subject in this study is "The lazy girl" fairytale. The data were collected from a synopsis "The Lazy Girl" of a fairy tale. The researchers watched the fairy tale on YouTube, then the researcher wrote the synopsis of a lazy girl fairy tale and took note of the character communication. In collecting the data, some steps were conducted: (a) Reading the whole synopsis (b) analyzing the texts in which the sentences used ideational function and (c) categorizing the sentences according to the types of ideational function. In this case, the researchers also analyzed the feminism theory and the moral value of the story. The data were analyzed based on SFG ideational meta-function analysis. The focused analysis was on the process of the type's ideational function. In a feminist framework, the researchers analyzed the data used in feminist literary analysis. In this case, the researchers used feminist literary analysis in the sentence which represents the ideology of feminism in the fairy tale "The Lazy Girl".

\section{FINDING AND DISCUSSION}

\section{Finding}

\section{Ideational meta-function analysis}

Theoretically, ideational function reflects the contextual value of the field (what's going on), it construes human experience. Ideational function concerned with resources for analyzing experience (Saragih, 2013). The process is subdivided into the material, mental, relational, and verbal. Practically, all types of processes were used as could be seen in the following data.

\section{a. Material process}

The material process is the process of doing or happening. One who acts as

an actor and the object of the action is the goal (Halliday, 2014) Based on this 
concept, the data analysis shows that this type of process in this text as shown in data 1.

\begin{tabular}{|c|c|c|}
\hline Actor & Material Process & Goal \\
\hline I & cleaned & The house \\
\hline I & Washing & Clothes \\
\hline & watering & Plants \\
\hline
\end{tabular}

From the data above, the word "cleaned, washing, and watering" was a material process because the word expressed physical action. It also had 1 participant (actor) "I" and goal represented in the use of "the house, clothes, and plants".

\section{b. Mental Process}

The mental process expresses mental phenomena such as perception (see, look), reaction (like, please), and cognition (know, believe, convince). The mental process involves two participants; they are senser and phenomenon (Halliday, 2014). Based on this concept, the data analysis showed that this type of process was found in this text as shown in data 2 below.

\begin{tabular}{|c|c|c|c|}
\hline Senser & Mental Process & Time & Phenomenon \\
\hline you & Love and care (affective) & & Of me \\
\hline I & Know (Cognitive) & One day & $\begin{array}{c}\text { My effort will be } \\
\text { rewarded }\end{array}$ \\
\hline She & Found (Perceptive) & & Dying vine \\
\hline
\end{tabular}

From data 2 above, the word "love and care" was a mental affective process because it expressed a feeling of senser. The word "know" was a mental cognitive process, because it expressed the thinking or cognition. While the word "found" was a mental perceptive process, it expressed perception. The senser is "you, I, and she". The word "me, my effort and dying vine" as the phenomenon.

\section{c. Relational process}

The relational process is a process of being. It is divided into attributive, identifying, and possessive. Attributive is constituted by carrier + attribute; identifying consists of token/identifier + value/identified; and possessive includes possessor + possessed. Based on this concept, the data below showed how the relational process existed in the narrative text. 
Data 3

\begin{tabular}{|c|c|c|}
\hline Token & Relational Process & Value \\
\hline This & Is (identifying relation) & Difficult \\
\hline You & Are (identifying relation) & Right \\
\hline She & Has (attributive relation) & Stepsister \\
\hline
\end{tabular}

From data 3 above, the word "is and are" was an identifying relational process type since the word expressed a process of identifying. And the word "has" was an attributive relation process. Besides, it also had the identifier "this, you and she" and the value "difficult, right and stepsister" as the identified or value part.

\section{d. Verbal process}

Verbal processes are processes of saying (Halliday, 1994). This process has a sayer, receiver/target, and verbiage as its participants. Based on this theory, the data analysis shows that this type of process is found in the text as shown in data 4.

\begin{tabular}{|c|c|c|}
\hline Sayer (addresser) & Verbal Process & Verbiage \\
\hline Her father & said & "My sweet daughter, I am sorry. \\
\hline Her stepmother & said & "you are right Ana" \\
\hline She & Response softly & "No father, don"t be sorry" \\
\hline
\end{tabular}

From the data above, the word "said" in the first and second sentences is a verbal process since the word expresses a process of saying, and it also has participants namely "her father and her stepmother" as a sayer. While in the third sentence, the word "she" as a sayer or addresser while the word "response" was a verbal process of addresser and the verbiage is "no father, don't be sorry" and the word father represents a 'receiver".

There were four types of ideational function process in "The Lazy Girl" fairytale. The finding summarized below:

Types of ideational function Process

\begin{tabular}{|c|c|c|c|}
\hline No & Types & Frequency & Percentage \\
\hline 1 & Material Process & 37 & $44 \%$ \\
\hline 2 & Mental Process & 17 & $20 \%$ \\
\hline 3 & Relation Process & 15 & $18 \%$ \\
\hline 4 & Verbal Process & 15 & $18 \%$ \\
\hline & Total & 84 & $100 \%$ \\
\hline
\end{tabular}

The table above represents the amount of each type of process used in "the

Lazy Girl" fairytale based on the synopsis. 


\section{Feminism Literary Analysis}

Feminist literary analysis is an approach that focuses on the way women are represented in literature. In this case, the interpretation is not only to understand how gender affects the character but also in understanding the societal values that are reflected by the work. Based on this concept was identified in "the lazy girl" synopsis and found several sentences that reflect the feminism theory.

\section{a. Brave}

"It's my turn now to take care of you. I'll work and earn a lot of money, this is difficult for us. It will be soon".

Based on the sentence above, "I'll work and earn money" is represent feminism. In this case, she dared to decide to replace her father to be the head of the family. Besides, she dared to leave the house and explore the forest by herself. Based on the feminist theory is included in the third-wive feminist theory.

\section{b. Hardworking}

She said, "I cleaned the house just this morning, I finished all house chores, I already washing clothes, washing dishes and watering plants." And "I have to work, nothing comes out of neglecting our duties".

From these Ana's statements are shows that she is hardworking. Ana introduced as a girl who has a good personality and a submissive young woman. She helped her stepmother to clean the house, washing dishes, watering plants, and washing the clothes. The word washing, watering plant" is the word that represents an action or activity done by participants. And the sentence "I cleaned the house just this morning" showed that the participant is finished all his job in the early morning, it represents hardworking. Based on the feminist theory is included in the second-wive feminist theory.

\section{The Moral Value}

Moral values are the standard by which we define right or wrong. It can come from herself, family, community, religion, and environment. In this research, the technique in delivering aspects of character education or moral value in the lazy girl fairy tale is consists of two forms, namely direct (Ana's speech) and indirectly (narrator's explanation).

\section{a. Direct speech}

Ana said "you were in need and I had to help you" and "I have to do and I will do it all my heart."

These speeches are shows that Ana has a good character and moral value. She likes to help and generous. The moral is a basic determination of which behavior is good as well bad by observing human action as far as their minds. The sentence 
"I had to help you" represents the good moral, it represents the kind of people and good behavior.

\section{b. Indirectly speech}

"In the middle of her journey, she found a dying vine, just beside the vine vane was a strange-looking spade the vine asked her help to take the spanned and plough the root. And then she ploughed till her palms were sore."

This part the narrator explained the moment when Ana helped the tree. The moral value of this part is a lifesaver. Ana showed a humble girl. She helps the dying vine with all her heart, although her hand hurts, she didn't care.

\section{Discussion}

Based on the finding above, it was concluded that all types of processes in the transitivity system were found in the synopsis of "The Lazy Girl" fairytale. There were four types of processes in the transitivity system namely: material process, mental process, relational process, and verbal process. All types of processes could be found in both synopses of "The Lazy Girl" fairytale because the essence of narrative text was to show the readers about the sequence of events along with the actions done by the participants. The researcher found that four main processes existed in fairytales' synopsis entitled these are material (44\%), mental (20\%), verbal (28\%), and relational process $(18 \%)$. Based on the data, the dominant one was the material process and followed by a mental process.

At the beginning of the story, Ana introduced as a girl who has a good personality and a submissive young woman. She helped her stepmother to clean the house, washing dishes, watering plants, and washing the clothes. She never complained to do it and every morning she did the house chores such as her habitual (hardworking). Based on Ana's action, she performed the traditional gender role, such as cleaning, washing, and other house chores. Ana's action shown the stereotype gender role, her representation of the traditional gender role, and performs many things traditionally associated with the woman role such as a housewife's work. It represents the third wave a feminist theory, the third-wave of a feminist which concerned with the social issues of women about the problem and phenomenon in that era. But in this wave, the woman stresses in choosing a more traditional role as a housewife.

Third-wave feminism began in a world in the 1990s which transforms from second-wave feminism. In this case, the third wave of feminism needs to transform from the traditional notions of sexuality and embrace of an exploration of women's feelings about sexuality (Lamb, 2010). In this case, some feminists change the connotation of feminists who only aim to control a woman's fertility (Hodgson \& 
Watkins, 1997). Feminists in the third wave experienced with the political issue, they experienced salary inequality, leave policy and lack of support for single mothers, for the working mothers who decided to leave their careers to raise their children full time and restrictions and social issues began to occur. This story show Ana's decision to work outside and help her family to earn the money. She decided it because she knows that her father becomes to week and ill, so she takes the responsibility of her family. Ana shows the power identity of women. In this case, Ana acts as the head of the household where she bears all her family in terms of economy. The dominant character of this story are women, which show the feminist theory that focuses on women's life.

Furthermore, the second wave of feminist theory was used in this story, it represents in Ana's action. She said "No Father, don't be sorry. You loved and care for me all my life! It's my turn now to take care of you. I'll work and earn a lot of money, this is difficult for us. It will be soon. According to Daniel statement, he states that the Second Wave of feminism was centered on social issues including a woman's right to enter the workforce and receive equal pay (Morrison, 2014). The second wave of feminist is about gender equality, where women have the same rights as men in the economy field, politics, and social values. Women can go to work out of the house and get the same salary as men in their job. In this period the feminists opposed discrimination that occurred to women. From Ana's action showed the brave girl characteristic. She takes the big responsibility to change the head household role in the economy field. She left to work and earn the money from their family. Ana's action showed the stereotype of gender equality.

Besides the moral values also showed by all the characters of this story. The first character is a good personality which showed by Ana, she is a brave girl, hardworking, honest, patient, and humble girl. The character Ana in this story give a positive impact on young children. She motivated the audience to have a good personality in real life. In line with that, character Ana that loved her father very much give the good moral value to love the parent and family. Also, Ana showed a humble girl. She helps the dying vine with all her heart, although her hand hurts, she didn't care.

The second character is her stepmother who has a bad personality. She is the angry mother and evil. She always angry and ask Ana to do everything for house chores. On the other hand, she wants Ana to get out of the house and send her to work outside and will ask Ana's money. The third character is his stepsister that showed the lazy girl. She didn't do anything and just sit around admiring her beauty. And the last character is Ana's father. Ana's father shown with a loving father. He loved Ana very much but because he getting ill, he feels sorry for Ana to let her work outside. 


\section{CONCLUSION}

There were four types of processes in the transitivity system namely: material process, mental process, relational process, and verbal process. All types of processes could be found in both synopsis of "The Lazy Girl" fairytale the story of "The lazy Girl". Besides, the researchers found that four main processes existed in fairytales' synopsis entitled these are material (44\%), mental (20\%), verbal (28\%), and relational process $(18 \%)$. Based on the data, the dominant one was the material process and followed by a mental process. Meanwhile, based on the feminist characteristic showed the second wave of feminist and third-wave feminism characteristics. The power equity was showed in this story based on Ana character. Besides, this story possesses strong moral values for children because this story represents the good personality of the main character Ana which inspired the children. Delivery of moral message in this fairytale "The Lazy Girl" is conveyed directly through the main character in the form of the action she takes. Furthermore, the children are easy to understand the moral clarity contained in it. The moral message is implied through a series of events in the story and character. Therefore, aspects of morals are part of the story element which easiest and commonly used as a means of conveying morality in the character and main character. The children need to take the good moral value on the story. Luilani said that "the finding of the fairytale is important because it gives good information about to makes the children having a good manner and how fairy tales are being a valid part of learning for the children (Tatar \& Princeton University Press, 2015). Fairy tales not only aid in child development but they also offer a rich source of material to draw from therapeutically.In this era, feminists and fairy tales are unity and interrelated. Therefore, for researchers to explore more deeply about feminist theory in a modern or classic fairy tale. On the other hand, Fairy tales also pay close attention to real moral value from the representative character and virtue. Besides the fairytale is good for children's' character, norms, and good behavior, fairy tales can be media to teach them.

\section{BIBLIOGRAPHY}

Al-Barazenji, L. I. (2015). Women's Voice and Images in Folk Tales and Fairy Tales. IJASOS-International E-Journal of Advances in Social Sciences, 1(1), 47. https://doi.org/10.18769/ijasos.45530

Beynen, G. K. (1977). Review of The Uses of Enchantment. The Meaning and Importance of Fairy Tales [Review of Review of The Uses of Enchantment. The Meaning and Importance of Fairy Tales, by B. Bettelheim]. The Slavic and East European Journal, 21(3), 396-398. JSTOR. https://doi.org/10.2307/306589

Dimerman, S. (2009). Character Is the Key: How to Unlock the Best in Our Children and Ourselves. John Wiley \& Sons.

Halliday, M. A. K., \& Matthiessen, C. M. I. (2004). An Introduction to Functional 
Grammar. London: Routledge.

Halliday, M. A. K. (1994). An Introduction to Functional Grammar. London: Edward Arnold

Hendricks, D. (n.d.). The rise of the super sidekick: A feminist analysis of girls in superhero film. August 2013.

Hodgson, D., \& Watkins, S. C. (1997). Feminists and Neo-Malthusians: Past and Present Alliances. Population and Development Review, 23(3), 469. https://doi.org/10.2307/2137570.

Justice, B. (2014). Maleficent Reborn: Disney's Fairytale View of Gender Reaches Puberty. Social Education, 78(4), 194-198.

Kuykendal, L. F., \& Sturm, B. W. (2007). We Said Feminist Fairy Tales, Not Fractured Fairy Tales! Children and Libraries, 5.

Lamb, S. (2010). Feminist Ideals for a Healthy Female Adolescent Sexuality: A Critique. Sex Roles, 62(5), 294-306. https://doi.org/10.1007/s11199-0099698-1.

Lazar, M. (2005). Feminist Critical Discourse Analysis: Gender, Power, and Ideology in Discourse. Springer.

Loobeek, K. (2014). A Feminist Analysis of the Film "The Hunger Games. Concordia Journal of Communication Research, 1(1). https://digitalcommons.csp.edu/comjournal/vol1/iss1/3.

Morrison, D. (2014). Brave: A Feminist Perspective on the Disney Princess Movie.

Paxton, T. (2005). Fairy tale into fantasy: Writing toward the healing of a woman's soul - ProQuest. https://search.proquest.com/openview/9ac0741f86cf40296ea4ccf8d7c9955e/1 ?pq-origsite $=$ gscholar $\& \mathrm{cbl}=18750 \&$ diss $=\mathrm{y}$.

Rudloff, M. (2016). (Post) feminist paradoxes: The sensibilities of gender representation in Disney's Frozen. Outskirts: Feminisms along the Edge, 35, D1-D1.

Saragih, A. (2013). Discourse Analysis: A Study on Discourse Based on Systemic Functional Linguistic Theory.

Tatar, M. (2017). The Classic Fairy Tales (Second International Student Edition) (Norton Critical Editions). W. W. Norton \& Company.

Tatar, M. (2015). Off with their heads!: Fairy tales and the culture of childhood. Princeton University Press. 